\title{
ОСОБЛИВОСТІ ПІДЛІТКОВОЇ ВАГІТНОСТІ У КРОПИВНИЦЬКОМУ ТА КІРОВОГРАДСЬКІЙ ОБЛАСТІ
}

\author{
М. В. Наконечна, Н. В. Петренко \\ ДВНз «Тернопільський державний медичний університет \\ імені І. Я. Горбачевського МОЗ України»
}

У статті проаналізовано особливості перебігу підліткової вагітності, пологів та стан новонароджених дітей юних мам.

\section{THE PECULIARITIES OF TEENAGE PREGNANCY IN KROPYVNYTSKYI AND KIROVOHRAD REGION}

\author{
M. V. Nakonechna, N. V. Petrenko

\section{Horbachevsky Ternopil State Medical University}

\begin{abstract}
The article analyzes the peculiarities of teenage pregnancy, the peculiarities of acts of delivery and the state of newborn babies of young mothers.
\end{abstract}

Вступ. Ранньою або підлітковою вагітністю прийнято вважати стан вагітності в дівчаток-підлітків віком 13-17 років. За даними ВООЗ, у світі на сьогодні проживає близько 13 млн людей, народжених жінками, які не досягли 18-річного віку [1]. Близько $90 \%$ випадків підліткової вагітності виявляють в країнах, що розвиваються $[2,5]$. На сьогодні понад 50 \% підлітків розпочинають статеве життя у віці 14-16 років. Майже $85 \%$ вагітностей у дівчаток до 18 років $\epsilon$ незапланованими. За світовою статистикою, 70 \% підліткових вагітностей завершуються абортами, 15 \% - самовільними викиднями і тільки 15 \% - пологами $[6,7]$. Дані літератури свідчать про те, що вагітність та пологи у юних мам мають ускладнений перебіг у 70-75 \% випадків [1, 8].

В Україні за рік офіційно фіксують в середньому 80 випадків переривання вагітності у дівчаток віком до 14 років та майже 3000 - у 15-17-річних [3]. Крім того, лише 40 \% матерів, яким ще немає 18 років, закінчують середню школу, а близько 80 \% хлопців не одружуються з юними матерями своїх дітей [4].

Все це дає підстави розглядати і ставитись до цього питання як не лише до акушерської, а й серйозної соціальної та психологічної проблеми, яка потребує подальшого вивчення та розробки заходів щодо ії попередження.

(C) М. В. Наконечна, Н. В. Петренко, 2018
Метою роботи було вивчення поширеності підліткової вагітності на теренах Кіровоградської області та особливостей перебігу таких вагітностей, пологів та стану новонароджених.

На основі аналізу медичної документації (індивідуальна карта вагітної та породіллі (форма 111/о)) проведено вивчення особливостей перебігу вагітності, пологів, післяпологового періоду та стан новонароджених у молодих дівчат віком до 18 років. у 2015-2017 рр. у Кіровоградській області таких пологів було 25. Нагляд за вагітними здійснювали згідно з наказом МОЗ України від 15.07.2011 р. № 417 «Про організацію амбулаторної акушерсько-гінекологічної допомоги в Україні».

До уваги брали соціальні фактори (місце проживання, зайнятість), менструальну, статеву, дітородну функції, застосування методів контрацепції, а також особливості перебігу цієї вагітності та пологів і стан новонароджених ними дітей.

Основна частина. У 2015-2017 рр. у Кропивницькому обласному центрі планування сім'і та репродукції людини відбулося 25 пологів у дівчат віком до 18 років, причому в 2015 р. їх було 8 (32 \%), у 2016 р. - 13 (52 \%), в 2017 р. - 4 (16\%).

Залежно від віку юні вагітні розподілились таким чином: 14-15 років - 1 (4\%) вагітна, 15-16 років 5 (20\%), 16-17 років - 8 (32\%), 17-18 років - 11 (44\%). 
Більшість вагітних (14 (56 \%)) були жительками міста Кропивницького, а 11 (44\%) - Кіровоградської області.

Як показали дослідження, 6 (24 \%) дівчат були ученицями середніх загальноосвітніх шкіл, 11 (44\%)студентками професійно-технічних училищ, 8 (28\%)студентками закладів вищої освіти.

Аналізуючи реєстраційні карти встановлено, що лише 9 (36 \%) вагітних перебували у зареєстрованому шлюбі, 10 (40 \%) -у громадянському шлюбі, а 6 (24\%) були одинокими.

Середній вік менархе серед обстежених вагітних склав $(13,8 \pm 2,5)$ року, причому пізнє менархе мало місце у 3 (12\%) дівчат. Аналізуючи характер менструальної функції встановлено, що у більшості дівчат (21 (84 \%)) менструальний цикл був регулярним, і тільки у 4 (16 \%) - нерегулярним, з частими затримками. Середня тривалість циклу складала $(28,2 \pm 3,1)$ дня, середня тривалість кровотечі - $(4,1 \pm 1,1)$ дня. Більшість дівчат (21 (84 \%) мали нормальні за об'ємом менструальні виділення, тільки 4 (16 \%) відзначали рясні виділення. Страждали від альгодисменореї 12 (48 \%) дівчаток.

Слід відзначити, що в такому юному віці 8 (32 \%) дівчат мали кандидозний кольпіт, а 1 (4 \%) - хламідіоз.

Аналіз статевої активності показав, що до настання вагітності у 19 (76 \%) дівчат був один статевий партнер, у 6 (24 \%) - 2, у 1 (4 \%) - 3. До настання вагітності 15 (60\%) дівчат мали регулярне статеве життя, а 10 (40 \%) - епізодичні статеві акти.

Аналіз використання методів контрацепції показав, що 18 (72 \%) підлітків мають досвід використання хоча 6 одного з методів контрацепції. До настання вагітності 9 (36 \%) дівчат застосовували презервативи, 7 (28 \%) - природні методи, 2 (8 \%) - сперміциди, а 7 (28 \%) не використовували жодного контрацептивного засобу.

Аналізуючи загальний стан соматичного здоров'я встановлено, що на обліку в сімейного лікаря перебувало 9 (36 \%) вагітних із приводу вегетосудинної дистонії, 4 (16\%) - хронічного пієлонефриту, 3 (12\%) хронічного холециститу, 1 (4 \%) - уродженої вади серця (недостатність аортального клапана), 1 (4 \%) бронхіальної астми, 1 (4\%) - реактивного гепатиту, 1 (4 \%) - залишкових явищ перенесеного туберкульозу легень, 1 (4 \%) - нефроптозу, 1 (4 \%) - хронічної залізодефіцитної анемії.
На облік з приводу вагітності до 12 тижнів стали 5 (20 \%) вагітних, у терміні 12-14 тижнів - 19 (76 \%), 1 (4 \%) вагітна на «Д» обліку не перебувала.

Аналізуючи перебіг вагітностей було встановлено, що акушерські ускладнення під час вагітності мали місце у 9 (36 \%) вагітних. Так, у 6 (24\%) вагітних гестаційний процес ускладнився загрозою переривання вагітності у I триместрі, у 2 (8 \%) - загрозою переривання вагітності у II триместрі, у 1 (4 \%) - дисфункцією плаценти.

У юних першовагітних перебіг вагітності ускладнився анемією І ст. у 9 (36 \%) жінок, анемією ІІ ст. в 2 (8 \%), гестаційним пієлонефритом - у 1 (4 \%), гіпотонією вагітних - в 1 (4 \%).

Необхідно відзначити, що серед обстежених жінок була 1 (4 \%) 17-річна повторно вагітна. Перша вагітність у неї в 15-річному віці закінчилась терміновими пологами. Всі інші 24 (96 \%) жінки були вагітні вперше.

Вагітність завершилася пологами у 24 (96 \%) вагітних, а в 1 (4 \%) - самовільним викиднем у 19 тижнів. Термінові пологи мали місце у 22 (64\%) жінок, а передчасні - у 2 (8 \%) вагітних.

Пологи через природні пологові шляхи відбулися у 20 (80 \%) вагітних, причому в 2 (8 \%) жінок проводили ручне відокремлення плаценти і виділення посліду.

Кесарів розтин проведено у 4 (16 \%) вагітних, із приводу сідничного передлежання плода 3 (12\%) та уродженої вади серця 1 (4 \%).

Всього молодими мамами було народжено 25 дітей, з них - 18 хлопчиків і 7 дівчаток. Усі діти народились живими. Середня маса $(3025,45 \pm 65)$ г, довжина $(48,68 \pm 1,5)$ см, оцінка за шкалою Апгар на

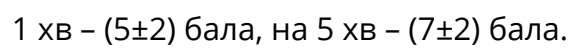

Висновки. 1. Усі юні вагітні належать до високої групи ризику щодо розвитку материнської та перинатальної патології.

2. Факторами ризику розвитку підліткової вагітності $\epsilon$ діти з неблагонадійних сімей, підлітки, які рано розпочинають статеве життя та в яких відсутнє статеве виховання.

3. Підліткова вагітність - це не лише акушерська, а й серйозна соціальна, психологічна проблема, яка потребує свого подальшого вивчення та розробки заходів її вирішення. 


\section{СПИСОК ЛІТЕРАТУРИ}

1. Быстрицкая Т. С. Беременность и гинекологическое здоровье у подростков / Т. С. Быстрицкая. - М. : Феникс, 2015. - 256 c.

2. Наймолодші мами у світі // Акушерство. Гінекологія. Генетика. - 2016. - Т. 2, № 4. - С. 94-96.

3. Андрієць О. А. Підліткова вагітність: актуальна проблема сьогодення / О. А. Андрієць, Л. В. Ринжук, О. І. Боднарюк // Акушерство. Гінекологія. Генетика. 2016. - Т. 2, № 4. - С. 77-80.

4. Астахов В. М. Ювенильная беременность как психосоциальная проблема / В. М. Астахов, О. В. Бацылева // Акушерство. Гінекологія. Генетика. - 2016. - Т. 2, № 4. C. 81-85.
5. Петрунько О. В. Актуальні проблеми сексуального виховання підлітків / О. В. Петрунько. - К. : ДЦССМ, 2014.

6. Островская Е. А. Медико-социальный прогноз последствий беременности и материнства в подростковом возрасте / Е. А. Островская // Репродуктивное здоровье детей и подростков. - 2014. - № 4. - С. 56-59.

7. Dianne S. E. Adolescent pregnancy / S. E. Dianne, E. F. Marianne // Pediatr. Clin. N. Am. - 2017. - No. 50. P. 781-800.

8. Emans S. J. H. Pediatric and Adolescent gynecology / 5th Edition / S. J. H. Emans, M. R. Laufer, D. P. Goldstein. Lippincott Williams \& Wilkins. - 2015. - No. 8. - P. 561-563.

Отримано 03.12.18 